\title{
Difference in reproduction energy content in muscles on fish from reservoirs in Paraná State, Brazil
}

\author{
Luis Alberto Espínola ${ }^{1}$, Elãine Christine dos Santos Dourado² and Evanilde Benedito ${ }^{3}$
}

\begin{abstract}
The variation in energy in the muscles of the most representative fish species from three Neotropical Reservoirs was investigated to determine the effect of the reproductive process on the amount of energy allocated and a possible relationship between the general welfare of the species and their caloric content. Significant differences were detected between the sexes and among the stages of gonad maturity. In general, the variation in energy in the muscles indicate to be a function of the reproductive cycle. In most examined species, females presented the highest caloric values, reflecting physiological differences in their use of energy, relative to the reproductive process. However, there was no significant correlation between caloric values and the condition factor of any species. Significant differences in the caloric content and condition factor were identified in each species belonging different trophic groups, indicating an effect of food quality on the amount of energy stored in the muscles. We conclude that the analyzed species presented a similar pattern of variation in energy, but that this was not reflected in their condition. In addition, an effect of reproduction and feeding habit on energy allocation was observed in both sexes.
\end{abstract}

Foi investigada a variação da energia nos músculos das espécies de peixes mais representativas de três reservatórios neotropicais, para determinar o efeito do processo reprodutivo na quantidade de energia alocada e uma possível relação entre o bem-estar geral das espécies e seu conteúdo calórico. Foram detectadas diferenças significativas entre os sexos e os estádios de maturidade gonadal. Em geral, a variação da energia nos músculos demonstra ser dependente do ciclo reprodutivo. Na maioria das espécies estudadas, as fêmeas apresentaram os maiores valores calóricos, refletindo as diferenças fisiológicas no uso de sua energia, em relação ao processo reprodutivo. No entanto, não houve correlação significativa entre os valores calóricos e o fator de condição as espécies estudadas. Diferenças significativas do conteúdo calórico e no fator de condição foram identificadas em cada espécie pertencente aos diferentes grupos trófcos, indicando um efeito de qualidade alimentar sobre a quantidade de energia armazenada nos músculos. Conclui-se que as espécies analisadas apresentaram um padrão semelhante de variação de energia, mas que isso não se refletiu em sua condição. Além disso, um efeito da reprodução e hábito alimentar, sobre a alocação de energia, foi observado em ambos os sexos.

Key words: Calorimetry, Condition factor, Freshwater fish, Paraná River basin, Trophic groups.

\section{Introduction}

One of the metabolic conflicts faced by an organism is whether to use its resources for biomass production (somatic or reproductive growth) or to meet the costs of maintenance activity (Calow, 1985; Kaspari et al., 2000; Hendry et al., 2001). In fish, the accumulation of caloric content and the patterns of allocation to metabolism, growth, and reproduction are essential for ecological success, mainly for those species that use energy reserves for migration and reproduction (Saldaña \& Venables, 1983; Nurnadia et al., 2011). This process of energy allocation can be influenced by the consumption of food, environmental conditions, and changes in the reproductive cycle (Pandian \& Vivekanandan, 1985). Several studies have shown seasonal differences in the caloric content of fish (Pandian \& Vivekanandan, 1985; Berg \& Bremset, 1998; Pedersen \& Hislop, 2001; Arim et al., 2007). These variations are usually associated with the reproductive cycle, feeding, and storage of energy reserves, which tend to be more noticeable as the individual becomes larger and reaches sexual maturity (Tytler \& Calow, 1985).

The pattern of caloric content allocation may differ according to the maturity of the individual, since reproductive activity as well as gonadal maturation imply the use of reserves obtained from food intake and from energy reserves deposited in different parts of the body, and in some cases

\footnotetext{
${ }^{1}$ National Institute of Limnology (CONICET-UNL), Santa Fe, Argentina. laespn@gmail.com

${ }^{2}$ Instituto Federal de Educação, Ciência e Tecnologia do Maranhão - Campus Zé Doca, Zé Doca, MA, Brazil. ecsdourado@ifma.edu.br

${ }^{3}$ Nupélia/PEA, Universidade Estadual de Maringá, Maringá, Paraná State, Brazil. eva@nupelia.uem.br (corresponding author)
} 
may lead to a decrease in metabolic processes and somatic production (Tytler \& Calow, 1985). Changes characteristics of the water (quantity and quality of food resources available to the fish) produced by flood pulses or the reservoirs may cause alterations in the welfare of the fish. These alterations can be quantified by the condition factor (Abujanra et al., 2009; Espínola et al., 2012). Variations in the condition factor (relationship between extrinsic and intrinsic variables and physiology of fish) and the caloric content of fish species have been used as indicators of physiological status and of changes in body composition (Encina \& GranadoLorencio, 1997; Paul et al., 1998). Different species present variations in accumulation and use of the caloric content. Thus these variations depend on habitat conditions, trophic category, food quality, and specific reproductive strategy (Huntingford et al., 2001; Fiorin et al., 2007). In general, studies that measure the caloric content have been used to quantify the energy used for reproduction (Huntingford et al., 2001; Jonsson \& Jonsson, 2005). On the other hand, other studies have shown how fish use the caloric content accumulated in the muscles in environments with seasonal variations in the water level (Junk, 1985; Huss et al., 2008).

Studies on how the energy allocation is distributed into growth and survival, and how accumulated energy reserves vary according to seasonal environments in young fish, have been conducted experimentally in lakes and under simulated environmental conditions in aquaria respectively (Bryan et al., 1996; Post \& Parkinson, 2001; Huss et al., 2008). Some studies were developed in natural freshwater systems (Glebe \& Leggett, 1981) and others have been performed in marine environments (Pedersen \& Hislop, 1981; Tirelli et al., 2006).

Despite the importance of studies on the energetic ecology of fish, few such studies have been performed in Brazil, and most have been performed on marine species (Ngan et al., 1993). For freshwater environments, some studies have been developed in the upper Paraná River floodplain (Doria \& Andrian, 1997; Penczak et al., 1999; Benedito-Cecilio \& Morimoto, 2002; Vismara et al., 2004; Rezende et al., 2008; Garcia et al., 2010, Espínola et al., 2012).

Espínola et al. $(2008,2010)$ examined the variation of the energetic content for two species of the Manso Reservoir, but the analyses relating to the energetic quantification of fish species have not yet been conducted between dammed environments. Consequently, studies that quantify energy allocation in fish populations in impounded environments will enable quantification of the energy available in these ecosystems, providing support for more efficient monitoring. Therefore, this study investigated the energy variation in the main fish species from three reservoirs of Paraná State, with the aim of addressing the following questions: i) Does reproduction affect energy allocation in fish in different trophic groups? ii) Do males and females show similar energy variation during gonadal maturation? iii) Is the energy stored in the muscles correlated with the general welfare of the fish species?

\section{Material and Methods}

Study areas. Sampling was conducted every three months between February and December 2002, in three reservoirs in Paraná State (Fig. 1), encompassing the rivers Iguaçu (Iraí and Segredo reservoirs) and Paranapanema (Rosana Reservoir).

Iraí Reservoir $\left(25^{\circ} 25^{\prime} 10^{\prime \prime} \mathrm{S} 49^{\circ} 06^{\prime} 49^{\prime \prime} \mathrm{W}\right)$ : this lies in the Iguaçu River basin, began operation in 1999, and is located between the municípios Quatro Barras and Piraquara, Pinhais. It covers $14.6 \mathrm{~km}^{2}$, has a long residence time $\left(>1\right.$ year), and is relatively shallow $\left(\mathrm{z}_{\max }\right.$ $=8 \mathrm{~m}$ ). In addition, it is considered to be one of the most eutrophic reservoirs in Paraná State (Júlio Jr. et al., 2005).

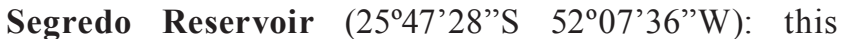
dam began operation in 1992, is the second in a series of four large reservoirs of the Middle Iguaçu River, and covers $80.6 \mathrm{~km}^{2}$. It is located around $455 \mathrm{~km}$ from the mouth of the river, and $2 \mathrm{~km}$ upstream of the mouth of Jordão River. In the region surrounding the reservoir, the climatic conditions follow the same pattern described for the basin, with average annual rainfall of $1,900 \mathrm{~mm}$, and no pronounced dry season (Júlio Jr. et al., 2005).

Rosana Reservoir ( $\left.22^{\circ} 36^{\prime} \mathrm{S} 52^{\circ} 50^{\prime} \mathrm{W}\right)$ : this is located in a stretch of the lower Paranapanema River, between the municípios Diamante do Norte (Paraná State) and Porto Primavera (São Paulo State), $25 \mathrm{~km}$ from the confluence with the Paraná River. It began operation in 1986, has an area of $220 \mathrm{~km}^{2}$, and is $116 \mathrm{~km}$ long. The land use in the area affected by this dam consists mostly of agriculture, pasture, reforestation, and rural properties, corresponding to almost $80 \%$ of the area of the entire basin (Júlio Jr. et al., 2005).

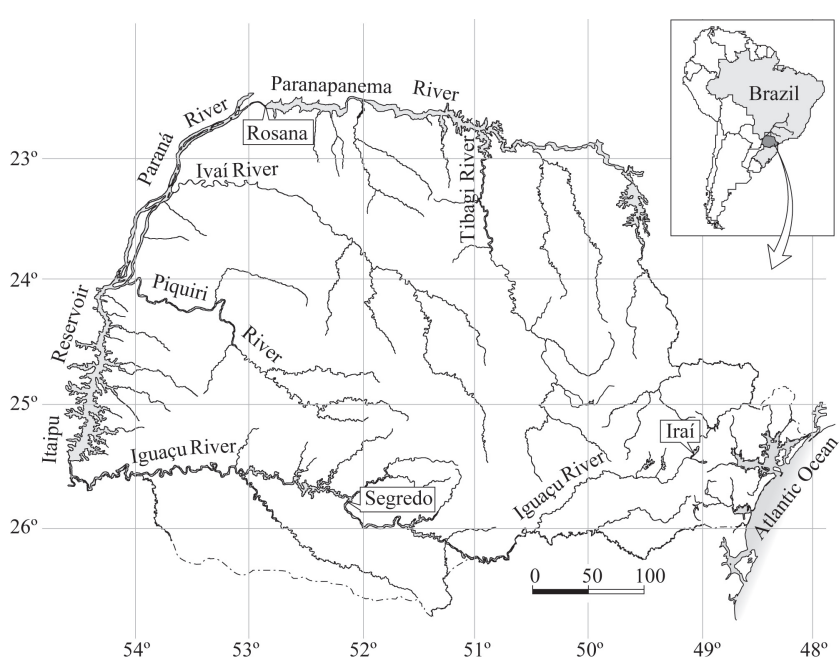

Fig. 1. Location of the reservoirs sampled in the present study, Paraná State. 
Collection and data analysis. Sampling was conducted using gillnets of different mesh sizes (2.4 to $16 \mathrm{~cm}$ between opposing knots), left in place for 24 hours. The most representative species were selected for each reservoir, based on the CPUE (catch per unit effort), considering the number of captured individuals per $1,000 \mathrm{~m}^{2}$ in 24 hours (Luiz et al., 2005). To estimate the calorie value per gram of dry weight, samples were taken from 615 individuals of abundant species belonging to the different trophic groups, according to Agostinho et al. (1997): Iraí - Hoplias aff. malabaricus (piscivore), Astyanax minor (detritivore), and Geophagus brasiliensis (invertivore); Segredo - Apareiodon vittatus (detritivore), Corydoras cf. paleatus (invertivore), and Astyanax bifasciatus (omnivore); Rosana - Loricariichthys platymetopon (detritivore), Satanoperca pappaterra (invertivore), and Acestrorhynchus lacustris (piscivore).

For each captured individual, data referring to standard length (SL) in centimeters, total weight (TW) in grams, sex, and gonad maturity stage were recorded. Macroscopic characters such as size, color, and vascularization, and visualization of oocytes, were used to determine the stages of maturity proposed by Vazzoler (1996). On average, eight individuals of each gonad maturity stage (resting - RES; early maturation EMT; maturing - MAT; mature - MTE; and spent - SPT) were analyzed for each sex (males and females), but not all stages were available. The presence of the EMT stage was justified by the need to extend the stages of maturity to include gonads that have already started the maturation process and those that already have growing oocytes (Vazzoler, 1981). In some cases, these two stages can be combined, but in terms of energetic content, the EMT stage shows a very distinct trend from the other stages in all species in which it has been characterized, and it was thus analyzed separately.

From each specimen, we extracted muscle samples from the base of the dorsal fin, for both sexes and at each gonadal maturation stage. The table 2 shows the number for each sex and gonadal maturation stage. All the samples were preserved in ice and taken to the laboratory of Energetic Ecology of Nupelia, where they were processed. Each sample was rinsed in distilled water and dried at $60^{\circ} \mathrm{C}$ in forced ventilation oven to constant weight. The dried muscles were ground in a ball mill to obtain a fine powder. The caloric value of the sample (kcal * g-1 dry weight) was determined by bomb calorimetry (PARR 1261) (Benedito-Cecilio \& Morimoto, 2002).

The physiological status of males and females was determined by the variation in the mean values of the condition factor $(\mathrm{K})$, according to the equation: $\mathrm{K}=$ (total weight / standard length)*100 (Vazzoler, 1996). The parameter " $b$ " was obtained for both sexes, by means of the regression between the standard length and total weight.
Considering that the assumptions of normality and homoscedasticity were not satisfied a Kruskal-Wallis test was applied to the data of caloric values $(\mathrm{kcal} / \mathrm{g})$ and condition factor $(\mathrm{K})$ of males and females, for the different gonad maturity stages of fish species in three reservoirs. A Mann-Whitney test was employed for intraspecific comparisons of the caloric values and condition factor, considering that the samples were independents. Spatial variations in caloric values and condition factor for each trophic group were presented graphically and tested with help of Kruskal-Wallis test. Then we carried out boxwhisker plots for depicting groups of numerical data through their medians, quartiles, minimum and maximum values. To identify a possible relationship between the caloric content and condition factor of the sampled individuals beyond that revealed by graphic inspection, the data were submitted to a linear correlation analysis (Zar, 1999). The analyses were performed with the support of the Statistica 7.0. The significance level adopted for all analyses was $\mathrm{p}<0.05$.

\section{Results}

There were significant differences in caloric values for each sexes, considering all different gonad maturity stages in each species analyzed. Nevertheless, only for some cases were the condition factor significantly different (Table 1).

Intraspecific comparisons of the caloric values of individuals at each stage of maturity revealed significant differences between sexes in most cases (Table 2). G. brasiliensis, $H$. aff. malabaricus, and L. platymetopon were the only species with significant differences between sexes during all stages. For the other species, from one to four maturity stages were significantly different in caloric values between males and females. Acestrorhynchus lacustris was the only species which showed no differences.

Individuals with early maturation of the gonads presented the lowest caloric values in the muscle. Likewise, specimens whose gonads were fully developed (mature stage - MTE) presented the highest caloric values in Iraí, Rosana and Segredo reservoirs (Table 2).

In both sexes of each species, the caloric values of the muscle increased significantly during gonadal development, achieving the highest mean at the stage of maximum reproduction and decreasing following the end of the reproductive period (Tables 1-2) and with significant values. Significantly differences caloric values and condition factor were observed between detritivorous, invertivorous, and piscivorous species $(\mathrm{p}<0.05)$ in all studied reservoirs, for both sexes (Figs. 2-3). The caloric values were the highest in $A$. minor (detritivore), $A$. bifasciatus (omnivore), and S. pappaterra (invertivore), depending of studied reservoir (Fig. 2) while for condition factor the invertivore species presented the higher values in all reservoirs. 
Table 1. Results of the Kruskal-Wallis test applied to the data of caloric values (kcal/g) and condition factor (K) of males and females, considering the different gonad maturity stages of fish species in three reservoirs in the Paraná State $\left(\mathrm{Df}_{\text {sta }}=\right.$ degree of freedom of the gonad maturity stage; $\mathrm{Df}_{\text {case }}=$ degree of freedom of each case; $\mathrm{H}=$ Kruskal-Wallis test; ${ }^{*}=$ significant difference).

\begin{tabular}{|c|c|c|c|c|c|c|c|}
\hline Reservoir & Species & Sex & Variable & $\mathrm{Df}_{\text {sta }}$ & $\mathrm{Df}_{\text {case }}$ & $\mathrm{H}$ & $\mathrm{p}$ \\
\hline \multirow{12}{*}{ IRAÍ } & \multirow{4}{*}{ Astyanax minor } & \multirow{2}{*}{ Female } & kcal & 4 & 59 & 47.63 & $0.00^{*}$ \\
\hline & & & $\mathrm{K}$ & 4 & 59 & 2.78 & 0.50 \\
\hline & & \multirow{2}{*}{ Male } & kcal & 4 & 45 & 31.29 & $0.00^{*}$ \\
\hline & & & $\mathrm{K}$ & 4 & 45 & 6.55 & 0.70 \\
\hline & \multirow{4}{*}{$\begin{array}{l}\text { Geophagus } \\
\text { brasiliensis }\end{array}$} & \multirow{2}{*}{ Female } & kcal & 3 & 32 & 24.61 & $0.00^{*}$ \\
\hline & & & $\mathrm{K}$ & 3 & 32 & 17.17 & $0.00^{*}$ \\
\hline & & \multirow{2}{*}{ Male } & kcal & 4 & 32 & 26.93 & $0.00 *$ \\
\hline & & & K & 4 & 32 & 18.42 & $0.00^{*}$ \\
\hline & \multirow{4}{*}{$\begin{array}{l}\text { Hoplias aff. } \\
\text { malabaricus }\end{array}$} & \multirow{2}{*}{ Female } & kcal & 4 & 19 & 12.30 & $0.00^{*}$ \\
\hline & & & $\mathrm{K}$ & 4 & 19 & 3.00 & 0.55 \\
\hline & & \multirow{2}{*}{ Male } & kcal & 3 & 26 & 14.25 & $0.00^{*}$ \\
\hline & & & $\mathrm{K}$ & 3 & 26 & 9.13 & $0.02 *$ \\
\hline \multirow{12}{*}{ SEGREDO } & \multirow{4}{*}{ Astyanax bifasciatus } & \multirow{2}{*}{ Female } & kcal & 3 & 50 & 44.52 & $0.00^{*}$ \\
\hline & & & $\mathrm{K}$ & 3 & 50 & 20.54 & $0.00 *$ \\
\hline & & \multirow{2}{*}{ Male } & kcal & 3 & 48 & 41.96 & $0.00^{*}$ \\
\hline & & & $\mathrm{K}$ & 3 & 48 & 15.12 & $0.01 *$ \\
\hline & \multirow{4}{*}{ Astyanax vittatus } & \multirow{2}{*}{ Female } & kcal & 4 & 41 & 32.19 & $0.00 *$ \\
\hline & & & $\mathrm{K}$ & 4 & 41 & 12.49 & $0.00^{*}$ \\
\hline & & \multirow{2}{*}{ Male } & kcal & 4 & 37 & 26.96 & $0.00 *$ \\
\hline & & & $\mathrm{K}$ & 4 & 37 & 16.79 & $0.01 *$ \\
\hline & \multirow{4}{*}{$\begin{array}{c}\text { Corydoras cf. } \\
\text { paleatus }\end{array}$} & \multirow{2}{*}{ Female } & kcal & 3 & 37 & 32.19 & $0.00 *$ \\
\hline & & & $\mathrm{K}$ & 3 & 37 & 1.77 & 0.62 \\
\hline & & \multirow{2}{*}{ Male } & kcal & 3 & 35 & 31.12 & $0.00 *$ \\
\hline & & & $\mathrm{K}$ & 3 & 35 & 9.12 & $0.02 *$ \\
\hline \multirow{12}{*}{ ROSANA } & \multirow{4}{*}{$\begin{array}{c}\text { Satanoperca } \\
\text { pappaterra }\end{array}$} & \multirow{2}{*}{ Female } & kcal & 3 & 17 & 11.33 & $0.01 *$ \\
\hline & & & $\mathrm{K}$ & 3 & 17 & 1.64 & 0.64 \\
\hline & & \multirow{2}{*}{ Male } & kcal & 4 & 23 & 17.86 & $0.01 *$ \\
\hline & & & $\mathrm{K}$ & 4 & 23 & 16.68 & $0.01 *$ \\
\hline & \multirow{4}{*}{$\begin{array}{c}\text { Loricariichthys } \\
\text { platymetopon }\end{array}$} & \multirow{2}{*}{ Female } & kcal & 4 & 34 & 31.20 & $0.00^{*}$ \\
\hline & & & $\mathrm{K}$ & 4 & 34 & 3.33 & 0.50 \\
\hline & & \multirow{2}{*}{ Male } & kcal & 3 & 29 & 22.97 & $0.00^{*}$ \\
\hline & & & $\mathrm{K}$ & 3 & 29 & 2.08 & 0.55 \\
\hline & & Female & kcal & 3 & 24 & 7.3 & $0.04 *$ \\
\hline & Acestrorhynchus & 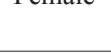 & $\mathrm{K}$ & 3 & 24 & 10.18 & 0.12 \\
\hline & lacustris & Male & kcal & 4 & 27 & 19.10 & 0.00 * \\
\hline & & IVIate & $\mathrm{K}$ & 4 & 27 & 5.79 & 0.20 \\
\hline
\end{tabular}


Table 2. Results of the Mann-Whitney test applied on the values of caloric (Kcal/g) values of males and females of fish species, at different gonad maturity stages $($ Res = Resting; Emt $=$ Early maturation; Mat = Maturing; Mte = Mature; $\mathrm{Spt}=$ Spent) from three reservoirs in the Paraná State. $\mathrm{N}_{\mathrm{F}}=$ number of females analyzed; $\mathrm{N}_{\mathrm{M}}$ = number of males analyzed; $\mathrm{U}=$ Mann-Whitney Test; $\mathrm{Z}(\mathrm{U})=$ standardized value of $\mathrm{U} ; *$ * significant difference.

\begin{tabular}{|c|c|c|c|c|c|c|c|c|c|}
\hline \multirow{2}{*}{ Reservoir } & \multirow{2}{*}{ Species } & \multirow{2}{*}{ Stage } & \multicolumn{2}{|c|}{ Median } & \multirow{2}{*}{$\mathrm{N}_{\mathrm{F}}$} & \multirow{2}{*}{$\mathrm{N}_{\mathrm{M}}$} & \multirow{2}{*}{$\mathrm{U}$} & \multirow{2}{*}{$\mathrm{Z}(\mathrm{U})$} & \multirow{2}{*}{$\mathrm{p}$} \\
\hline & & & Females & Males & & & & & \\
\hline \multirow{12}{*}{ IRAÍ } & \multirow{5}{*}{ Astyanax minor } & Res & 5.27 & 5.26 & 10 & 3 & 14 & 0.17 & 0.87 \\
\hline & & Emt & 5.21 & 5.25 & 6 & 2 & 0.11 & 2.55 & $0.01 *$ \\
\hline & & Mat & 5.32 & 5.35 & 23 & 20 & 22 & 2.67 & $0.01 *$ \\
\hline & & Mte & 5.36 & 5.38 & 10 & 10 & 10 & 3.02 & $0.00^{*}$ \\
\hline & & Spt & 5.26 & 5.25 & 10 & 10 & 174 & 0.45 & $0.00^{*}$ \\
\hline & \multirow{3}{*}{$\begin{array}{l}\text { Geophagus } \\
\text { brasiliensis }\end{array}$} & Res & 5.18 & 5.21 & 10 & 11 & 1.50 & 3.77 & $0.00^{*}$ \\
\hline & & Emt & 5.14 & 5.15 & 10 & 10 & 22 & 2.12 & $0.03^{*}$ \\
\hline & & Spt & 5.23 & 5.24 & 10 & 7 & 34.50 & 1.94 & $0.04 *$ \\
\hline & \multirow{4}{*}{$\begin{array}{l}\text { Hoplias aff. } \\
\text { malabaricus }\end{array}$} & Res & 5.15 & 5.13 & 8 & 10 & 28.00 & 1.07 & $0.02 *$ \\
\hline & & Emt & 5.05 & 5.02 & 2 & 6 & 10.00 & 0.43 & $0.04 *$ \\
\hline & & Mat & 5.18 & 5.16 & 5 & 6 & 4 & 0.71 & $0.03 *$ \\
\hline & & Spt & 5.16 & 5.12 & 2 & 4 & 0 & 2.84 & $0.00^{*}$ \\
\hline \multirow{13}{*}{ SEGREDO } & \multirow{4}{*}{ Astyanax bifasciatus } & Res & 5.23 & 5.22 & 10 & 11 & 17.5 & 2.64 & $0.01 *$ \\
\hline & & Mat & 5.31 & 5.32 & 20 & 17 & 24 & 0.65 & $0.00^{*}$ \\
\hline & & Mte & 5.35 & 5.34 & 10 & 10 & 12.5 & 2.83 & $0.00^{*}$ \\
\hline & & Spt & 5.26 & 5.25 & 10 & 10 & 200.5 & 0.25 & 0.80 \\
\hline & \multirow{5}{*}{ Apareiodon vittatus } & Res & 5.21 & 5.21 & 2 & 2 & 4 & 1.15 & 0.25 \\
\hline & & Emt & 5.20 & 5.21 & 9 & 6 & 6 & 2.47 & $0.01 *$ \\
\hline & & Mat & 5.21 & 5.22 & 17 & 11 & 18 & 2.42 & 0.06 \\
\hline & & Mte & 5.24 & 5.22 & 3 & 10 & 0 & 2.54 & $0.01 *$ \\
\hline & & Spt & 5.20 & 5.21 & 10 & 8 & 69 & 0.40 & 0.69 \\
\hline & \multirow{4}{*}{$\begin{array}{c}\text { Corydoras } \mathrm{cf} . \\
\text { paleatus }\end{array}$} & Res & 5.16 & 5.16 & 2 & 9 & 13 & 0.77 & 0.44 \\
\hline & & Mat & 5.21 & 5.21 & 15 & 12 & 8 & 0.49 & 0.62 \\
\hline & & Mte & 5.26 & 5.25 & 10 & 6 & 5.5 & 2.66 & $0.01 *$ \\
\hline & & Spt & 5.19 & 5.20 & 10 & 8 & 125 & 1.11 & 0.27 \\
\hline \multirow{9}{*}{ ROSANA } & \multirow{3}{*}{$\begin{array}{c}\text { Satanoperca } \\
\text { pappaterra }\end{array}$} & Res & 5.21 & 5.20 & 2 & 3 & 0 & 2.12 & $0.03^{*}$ \\
\hline & & Mte & 5.24 & 5.24 & 2 & 2 & 4 & 1.15 & 0.25 \\
\hline & & Spt & 5.21 & 5.16 & 9 & 2 & 61.5 & 0.28 & 0.78 \\
\hline & \multirow{3}{*}{$\begin{array}{l}\text { Loricariichthys } \\
\text { platymetopon }\end{array}$} & Res & 5.15 & 5.17 & 10 & 10 & 2 & 3.63 & $0.00^{*}$ \\
\hline & & Emt & 5.10 & 5.05 & 5 & 15 & 0 & 3.27 & $0.00^{*}$ \\
\hline & & Spt & 5.13 & 5.14 & 8 & 3 & 32 & 1.00 & $0.00^{*}$ \\
\hline & \multirow{3}{*}{$\begin{array}{l}\text { Acestrorhynchus } \\
\text { lacustris }\end{array}$} & Res & 5.11 & 5.12 & 5 & 4 & 3.5 & 1.59 & 0.11 \\
\hline & & Mte & 5.14 & 5.14 & 12 & 11 & 62.5 & 0.22 & 0.83 \\
\hline & & Spt & 5.14 & 5.12 & 1 & 1 & 7 & 0.80 & - \\
\hline
\end{tabular}



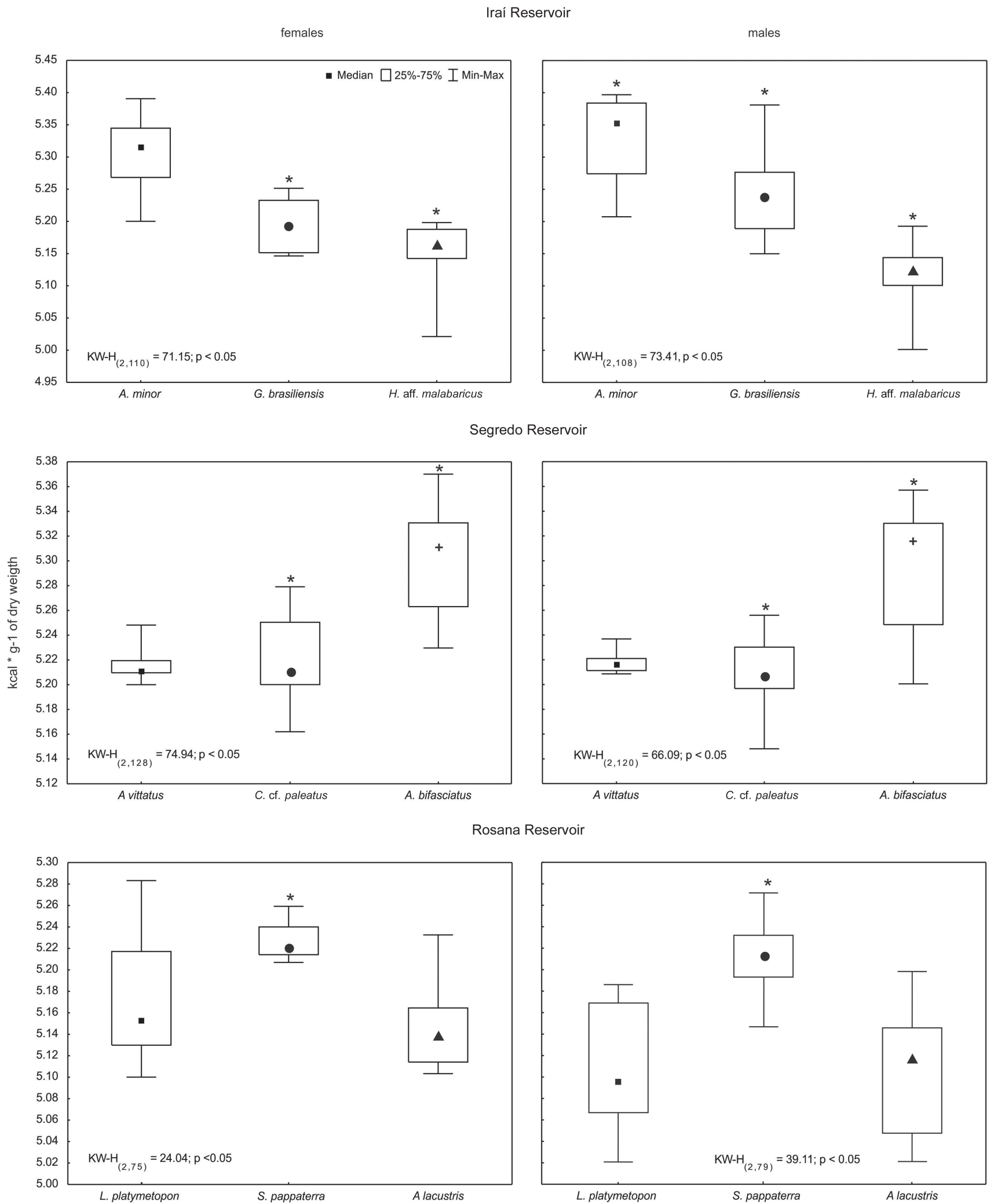

Fig. 2. Spatial variation (median, quartiles, maximum and minimum values) for caloric values in kcal * g-1 dry weight of males and females of Acestrorhynchus lacustris, Apareiodon vittatus, Astyanax bifasciatus, Astyanax minor, Corydoras cf. paleatus, Geophagus brasiliensis, Hoplias aff. malabaricus, Loricariichthys platymetopon, and Satanoperca pappaterra of different trophic groups (square - detritivorous, dot - invertivorous, triangle - piscivorous, cross - omnivorous) in three reservoirs in Paraná State $(\mathrm{KW}-\mathrm{H}=$ values of $\mathrm{H}$ of Kruskal-Wallis test $-*=$ significant difference $)$. 
females

Iraí Reservoir
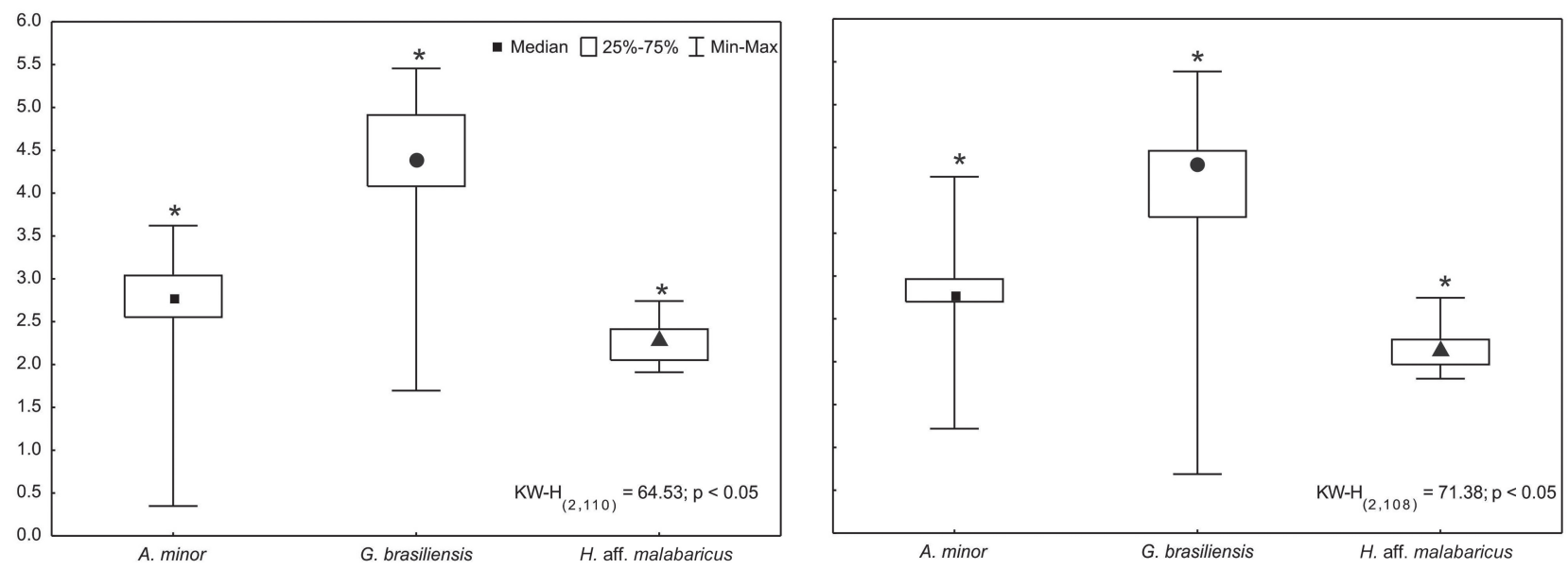

Segredo Reservoir
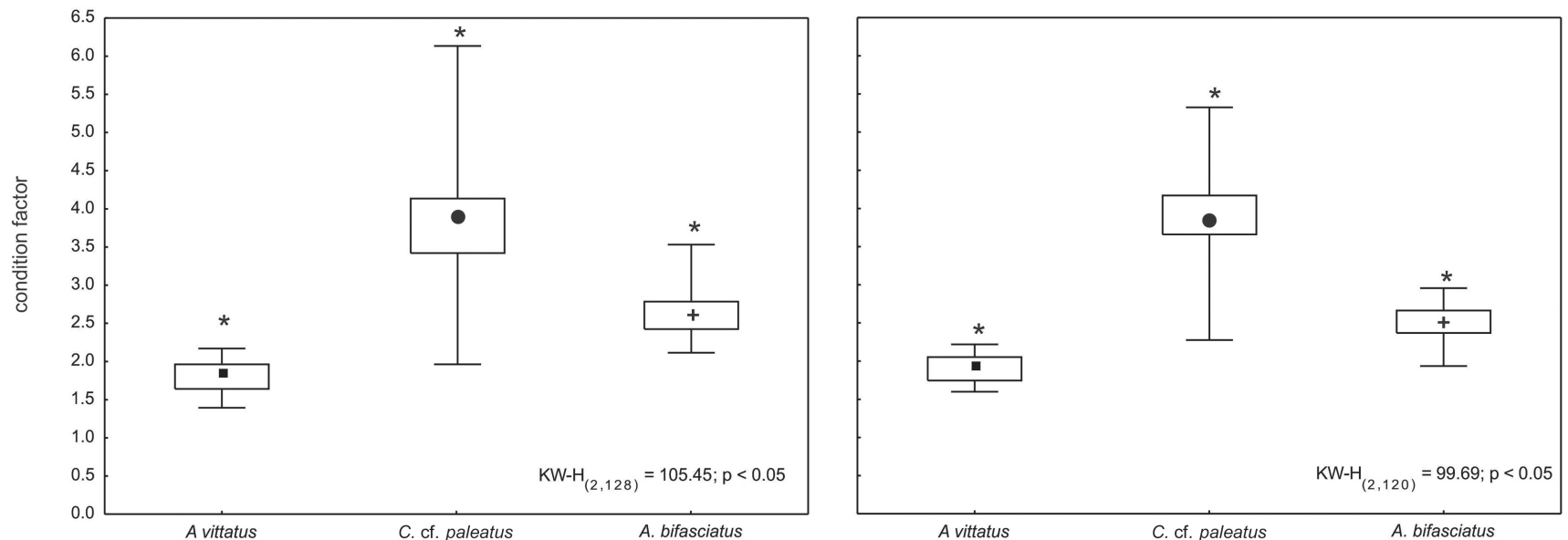

Rosana Reservoir
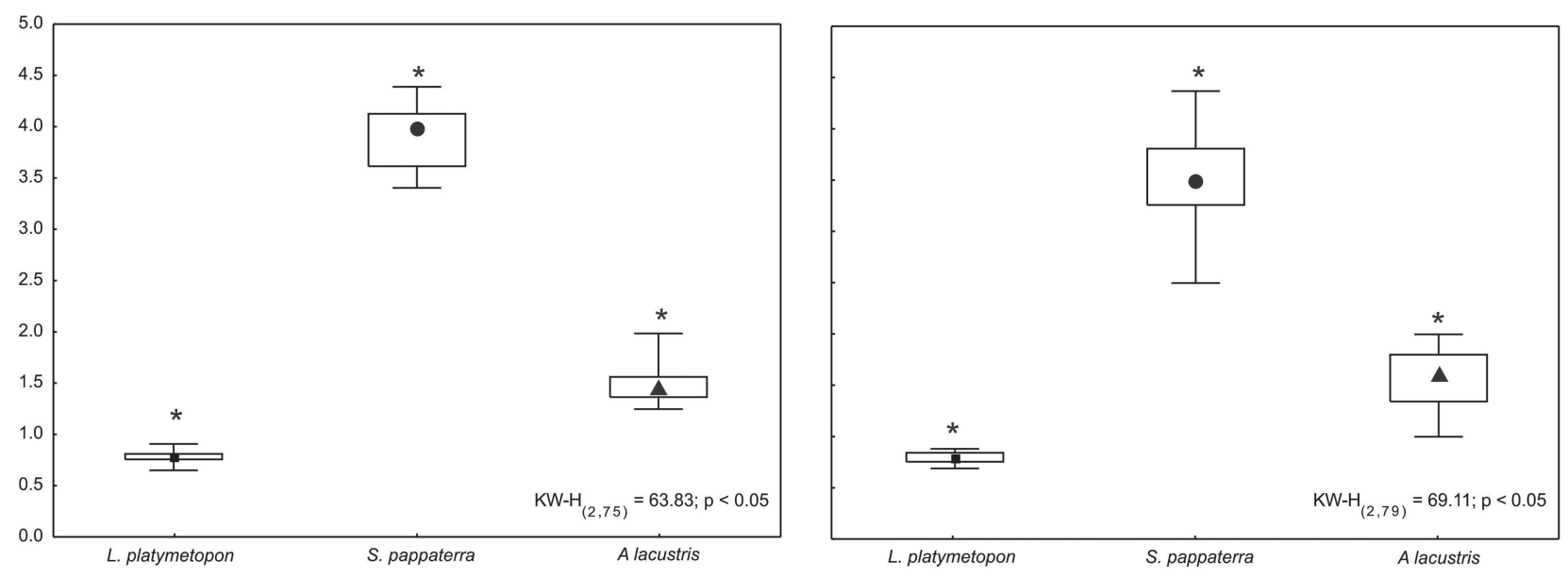

Fig. 3. Spatial variation (median, quartiles, maximum and minimum values) for condition factor of males and females of Acestrorhynchus lacustris, Apareiodon vittatus, Astyanax bifasciatus, Astyanax minor, Corydoras cf. paleatus, Geophagus brasiliensis, Hoplias aff. malabaricus, Loricariichthys platymetopon, and Satanoperca pappaterra of different trophic groups (square - detritivorous, dot - invertivorous, triangle - piscivorous, cross - omnivorous) in three reservoirs in Paraná State $(\mathrm{KW}-\mathrm{H}=$ values of $\mathrm{H}$ of Kruskal-Wallis test $-*=$ significant difference). 
Moreover, there was no significant correlation between the condition factor and caloric values in all species examined in the present study.

Significant differences in condition factor between males and females were not found for any species from Rosana and
Segredo reservoirs, except for $A$. bifasciatus from the latter reservoir. For $A$. bifasciatus and species from Iraí Reservoir differences were detected for only one gonad maturity stage (Table 3). These findings could indicate that the value of $\mathrm{K}$ varied depending on the sex and reservoir.

Table 3. Results of the Mann-Whitney test applied on the values of condition factor of males and females of fish species, at different gonad maturity stages $($ Res $=$ Resting; Emt $=$ Early maturation; Mat $=$ Maturing; Mte $=$ Mature; $\mathrm{Spt}=$ Spent $)$ from three reservoirs in the Paraná State. $\mathrm{N}_{\mathrm{F}}=$ number of females analyzed; $\mathrm{N}_{\mathrm{M}}=$ number of males analyzed; $\mathrm{U}=$ Mann-Whitney Test; $\mathrm{Z}(\mathrm{U})=$ standardized value of $\mathrm{U} ; *=$ significant difference.

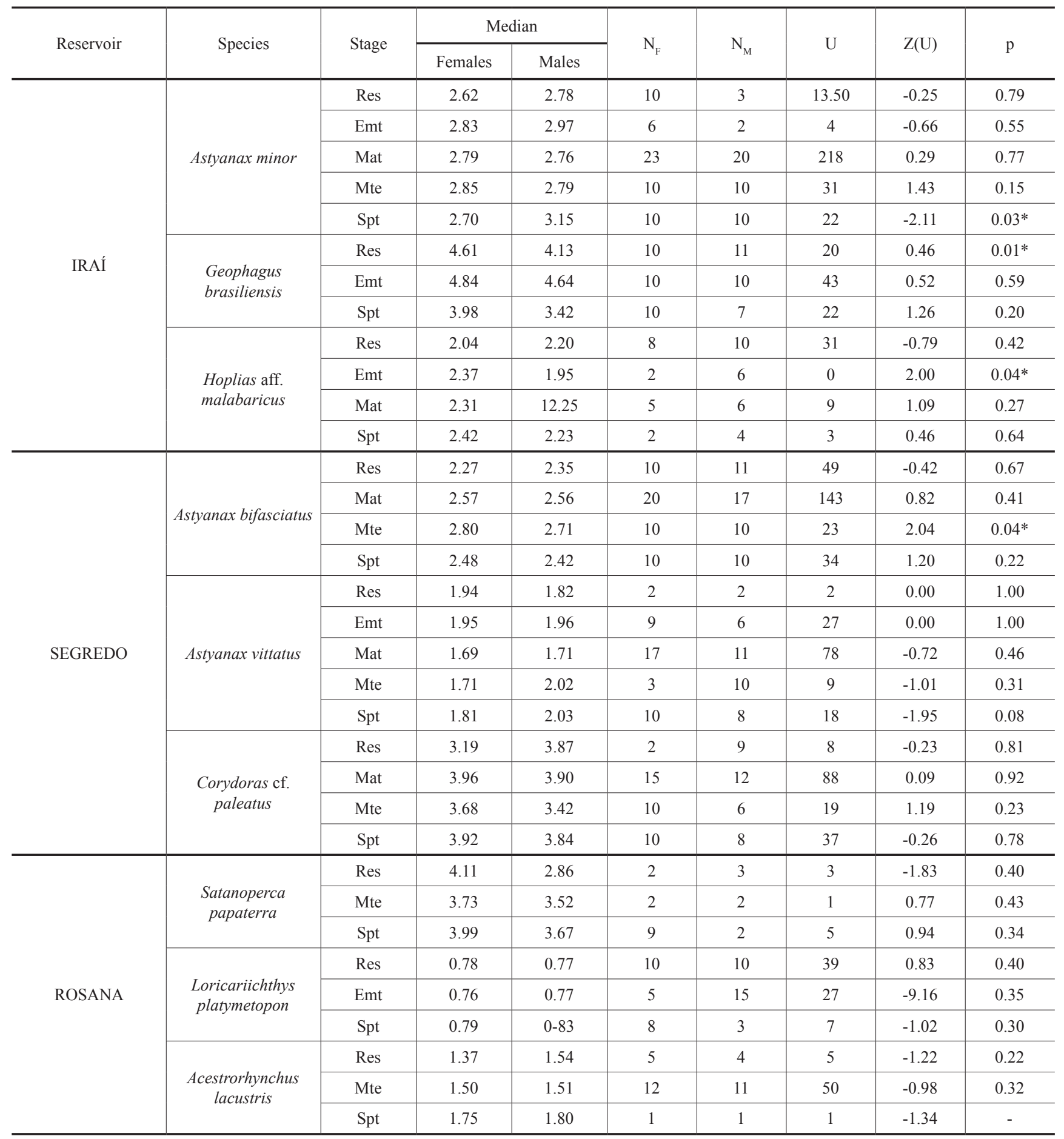




\section{Discussion}

Significant differences in caloric values were detected between the sexes. Females of many species use more of their energy reserves as they expend more energy during oocyte maturation, due to the production of larger gametes than in males (Vazzoler, 1996; Jonsson \& Jonsson, 1998). However, an exception was observed in Iraí Reservoir where the males had more energy in their muscle tissue. This result may be associated with the reproductive tactics displayed by the species analyzed, especially when considering A. minor and G. brasiliensis. For the family of $G$. brasiliensis, the males present sexual dimorphism at the time of reproduction, involving small differentiating structures or even brightly colored patterns (Breder \& Rosen, 1966). These characteristics demand energy and may be related to the high amount of energy recorded in the males from this reservoir.

The reproductive success of an organism is greatly influenced by how the available energy in its body is divided between somatic growth, gonadal development, and metabolic activities (Watt, 1986). In general, the pattern of energy in the muscles varied as a function of the reproductive cycle. Individuals in the early stages of maturation presented the lowest caloric content, with energy subsequently increasing during development. The maximum caloric values were achieved when the gonads were at the advanced stage of maturity, with a reduction after spawning. Prus (1970) reported that the highest caloric contents were observed during periods preceding food shortage or during reproduction. On the other hand, the amount of energy was lower until the start of the reproductive process in all species. This reduction may be related to spawning activity, which influenced the individuals for a longer period in comparison to other periods. It is possible that the impounded environment may impose limitations, both biotic and abiotic, that should be investigated in more detail in new studies.

Although the above-mentioned pattern was observed in most of the studied species, a different trend was observed in males of $H$. aff. malabaricus in Iraí Reservoir and of $L$. platymetopon in Rosana Reservoir, and also in females of C. cf. paleatus in Segredo Reservoir. In these three species, individuals with gonads at the resting stage showed an increase in energy after spawning, which was more pronounced in the latter two species. On the other hand, when analyzing the effect of gonadal maturation on the caloric content of fish species of the upper Paraná River floodplain, Vismara et al. (2004) observed the opposite trend in males of L. platymetopon. Moreover, the authors reported caloric densities for this species that were lower than those found in the present study, for both sexes (ranging from 4.65 to $5.15 \mathrm{kcal} * \mathrm{~g}-1$ dry weight in females, and 4.65 to $5.11 \mathrm{kcal}$ * g-1 dry weight in males). In accordance with Abujanra et al. (2009), the retention of nutrients and sediment behind the Porto Primavera Dam upstream causes the dilution of nutrients and reduction in drifting food organisms, and it intensifies the effects of the floods on the body condition of the fish.

Hoplias aff. malabaricus, L. platymetopon, and C. cf. paleatus have split spawning, external fertilization, and parental care, respectively (Suzuki \& Agostinho, 1997; Nakatani et al., 2001). Males of $H$. aff. malabaricus exhibit aggressive behavior when taking care of the nest, reacting to the presence of any potential predator (Querol et al., 2003). On the other hand, males of L. platymetopon have several genital papillae, under the lower lip, as accessory sexual characteristics, which are used to carry the egg mass (Nakatani et al., 2001). Thus rapid recovery of energy can be required to meet the expenses of behavioral aspects such as parental care.

According to Suzuki et al. (2000), split spawning requires a larger amount of energy for the process of gonadal maturation. During the resting stage, the gonads are prepared in order to start a new reproductive cycle, but in females of $C$. cf. paleatus it was found that the process of energy storage in the muscles began immediately after spawning. Thus, due to the intensification of this process, more energy may be stored in the muscles of females of this species for subsequent mobilization for reproduction.

The availability and quality of food are primary factors in the distribution of energy to different physiological processes in fish (Adams et al., 1982). Any factor altering the availability and quality of the food supply (density, abundance, and composition) will also change the energy input via changes in food intake, and consequently the entire allocation process. Significant differences were identified between species according to their feeding habits, indicating an effect of food quality on the amount of energy stored in the muscles. Lower numbers of calories per gram of dry weight were recorded for piscivorous species in the two environments in which they occurred. The highest caloric values varied between detritivores, omnivores and invertivores species, depending of reservoir analyzed. This fact indicates that the caloric values and composition of resources consumed were different in each reservoir. Odum (1988) stated that the amount of energy decreases along the trophic chain, but that the quality of the energy actually converted increases. In this way, as the amount of energy decreases, the quality of the energy in the trophic chain components increases, as observed for piscivores and invertivores. This species included higher quantity of animal organisms in its diet if compared to others trophic groups.

In the reservoirs with the highest nutrient concentrations (Iraí and Segredo), the species with the highest caloric content belonged to the genus Astyanax (A. minor and A. bifasciatus). These are considered to be opportunistic species, which show appropriate strategies in impacted environments such as reservoirs. In general, species of this genus are small and produce small oocytes, showing high relative fertility, rapid development, external fertilization, and no parental care - characteristics that enable them 
to rapidly colonize these environments (Agostinho et al., 1999). In addition, when analyzing the reproductive characteristics of these species in reservoirs from the Iguaçu River basin, Bailly et al. (2005) recorded higher values of RGS (gonadosomatic index) during the period of reproduction, as well as proportionately larger and heavier gonads, indicating proportionally higher allocation of energy and matter for reproduction.

The condition factor $(\mathrm{K})$ reflects physical and biological state and fluctuations by interaction between feeding conditions, parasitic infections and physiological factors (Le Cren 1951). In this study, the condition factor was always elevated among invertivores, showing that this resource promoved higher well being state if compared to others throphic groups analysed. This also indicates the food reserves shoud have been elevated in all reservoir. So, in some cases, especially in impacted environment, the information on condition factor can be vital to the management because it indicate which organisms are developing (Araneda et al., 2008).

Therefore, there was no significant correlation between this index and the caloric content of the species, although similar trends occurred in some cases. Other studies conducted in the upper Paraná River floodplain also found no correlation between these two variables (Doria \& Andrian, 1997). Meanwhile, studies in temperate regions where seasonal variations are more marked have shown the relationship between condition factor and the energy content of fish species (Herbinger \& Friars, 1991; BeneditoCecilio et al., 2005). Fluctuations in the energy reserves of structures related to reproduction or feeding that influence the physiology of the organism can be identified through variations in the condition factor (Le Cren, 1951; Soofiani \& Hawkins 1982; Encina \& Granado-Lorencio, 1997).

Through the quantification of energy balance parameters, one can identify critical periods of energy demand for the animal and study trophic relationships at the population level. One important parameter in this quantification is the caloric values, the values of which, in many cases, have been considered constant and equivalent, regardless of factors such as seasonality and trophic group. Nevertheless, several authors consider the use of fixed values of energy as inappropriate (Prus, 1970; Kitchell et al., 1977; Bryan et al., 1996) since variations in the caloric values of different trophic groups may affect the calculation of consumption, production, and conversion efficiency. In the present study, significant intra- and interspecific differences in caloric densities were observed, showing that they should be considered when modeling energy flow.

Espínola et al. (2012) observed that the condition factor of Cichla kelberi was lower in Baía River than in Paraná River, suggesting the influence of the flow regulation by an upstream reservoir (Porto Primavera), with increased transparency due to the retention of fine particles in that reservoir. This process could be facilitating the capture of preys with better nutritional value (Abujanra et al., 2009).
The process of retention of sediment is more evident in cascade reservoirs, such as Rosana and Segredo, which present transparencies of 2.1 and $1.35 \mathrm{~m}$ respectively. Although the Iraí Reservoir has a low transparency $(0.95$ m) (Júlio Jr et al., 2005) compared with other studied reservoirs, the retention of sediment could ease the capture of especially piscivorous and omnivorous species.

Based on the above, we conclude that the species of this study presented a cyclical and similar pattern of energy variation, but this was not reflected in their condition. In addition, an effect of reproduction and feeding habit on the energy allocation was observed for both sexes. Therefore, our results indicate the lack of difference in energy allocation and condition factor between reservoirs, but depending on physical characteristics of the reservoirs (sediment retention), piscivorous and omnivorous species are favored.

\section{Acknowledgments}

The authors wish to express their gratitude to the post-graduate course on the Ecology of Inland Aquatic Environments for financial support, and to CAPES for a scholarship; to the field team of PRONEX/2002; to the laboratories of the Trophic Ecology of Fish and Fish Systematics of Nupélia/UEM; to Érica Ikedo and Harumi Suzuki, for help in identifying the stages of gonad maturity; to Prof. Dr. Luiz Carlos Gomes for correcting the abstract and by statistic discussion; and to friends and colleagues of the laboratory of Energetic Ecology of Nupélia, for help in collecting the biological data. They are also grateful to the anonymous reviewers whose suggestions undoubtedly improved the final manuscript.

\section{Literature Cited}

Abujanra, F., A. A. Agostinho \& N. S. Hahn. 2009. Effects of the flood regime on the body condition of fish of different trophic guilds, in the Upper Paraná River floodplain, Brazil. Brazilian Journal of Biology, 69: 469-479.

Adams, S. M., R. B. McLean \& J. A. Parrot. 1982. Energy partitioning in largemouth bass under conditions of seasonally fluctuating prey availability. Transactions of the American Fisheries Society, 111: 549-558.

Agostinho, A. A., N. S. Hahn, L. C. Gomes \& L. M. Bini. 1997. Estrutura trófica. Pp. 229-248. In: Vazoller, A. E. A., A. A. Agostinho \& N. S. Hahn(Eds.). A planície de inundação do alto rio Paraná: aspectos físicos, biológicos e socioeconômicos. EDUEM, Maringá.

Agostinho, A. A., L. E. Miranda, L. M. Bini, L. C. Gomes, S. M. Thomaz \& H. I. Suzuki. 1999. Patterns of colonization in neotropical reservoirs and prognoses on aging. 1999. Pp. $227-$ 265. In: Tundisi, J. G. \& M. Straskraba (Eds.). Theoretical reservoir ecology and its applications. Backhuys Publishers, São Carlos.

Araneda, M., E. P. Perez \& L. E. Gasca. 2008. White shrimp Penaeus vannamei culture in freshwater at three densities: condition state based on length and weight. Aquaculture, 283: 
$13-18$.

Arim, M., F. Bozinovic \& P. A. Marquet. 2007. On the relationship between trophic position, body mass and temperature: reformulating the energy limitation hypothesis. Oikos, 116: 1524-1530.

Bailly, D., A. A. Agostinho, H. I. Suzuki \& E. A. Luiz. 2005. Características reprodutivas de espécies de Astyanax e sucesso na colonização de reservatórios do rio Iguaçu, PR. Pp. 243-252. In: Rodrigues, L., S. M. Thomaz, A. A. Agostinho \& L. C. Gomes (Eds.). Biocenoses em Reservatórios: padrões espaciais e temporais. São Carlos, Editora RiMa.

Benedito-Cecilio, E. \& M. Morimoto. 2002. Effect of preservatives on caloric density in the muscles of Hoplias malabaricus (Bloch, 1794) (Osteichthyes, Erythrinidae). Acta Scientiarum, Biological Sciences 24: 489-492.

Benedito-Cecilio, E., A. L. Pereira, A. C. A. Faria \& H. Baleroni. 2005. Effects of habitat on physiological indicators in Leporinus friderici (Pisces, Anostomidae) in the influence area of the Corumbá reservoir, Goiás, Brazil. Acta Limnologica Brasiliensia, 17: 71-79.

Berg, O. K. \& G. Bremset. 1998. Seasonal changes in the body composition of young riverine Atlantic salmon and brown trout. Journal of Fish Biology, 52: 1272-1288.

Breder, C. M. \& D. E. Rosen. 1966. Modes of reproduction in fishes. T. F. H. Publications, Neptune City, New Jersey.

Bryan, S. D., C. A. Soupir, W. G. Duffy \& C. E. Freiburger. 1996. Caloric densities of three predatory fishes and their prey in Lake Oahe, South Dakota. Journal of Freshwater Ecology, 11: 153-161.

Calow, P. 1985. Adaptative aspects of energy allocation. Pp. 1-31. In: Tytler, P. \& P. Calow (Eds.). Fish Energetics: news perspectives. Croom Helm, Sydney.

Doria, C. R. \& I. F. Andrian. 1997. Variation in energy content of somatic and reproductive tissues related to the reproductive cycle and feeding of female Pimelodus maculatus Lacépède, 1803 (Siluriformes, Pimelodidae) and Schizodon borellii Boulenger, 1985 (Characiformes, Anostomidae). Revista UNIMAR, 19: 421-437.

Encina, L. \& C. Granado-Lorencio. 1997. Seasonal changes in condition, nutrition, gonad maturation and energy content in barbel, Barbus sclateri, inhabiting a fluctuating river. Environmental Biology of Fishes, 50: 75-84.

Espínola, L. A., E. P. dos Santos, W. M. Domingues \& E. Benedito. 2010. Conteúdo calórico de músculos de Prochilodus lineatus (Characiformes, Prochilodontidae) no reservatório de manso, Brasil. Interciencia, 35: 445-449.

Espínola, L. A., H. F. Júlio Jr., E. Benedito. 2012. Invasive nonnative species of fish in Upper Paraná river Basin, Brazil: variations of caloric content in Cichla kelberi. Neotropical Ichthyology, 10: 8-16.

Espínola, L. A., W. M. Domingues \& E. Benedito. 2008. Variaciones en el contenido de energía en músculos de Salminus brasiliensis en diferentes estados de desenvolvimiento gonadal en el área de influencia del reservatório de Manso, Mato Grosso, Brasil. Iheringia, 98: 1-5.

Fiorin, R., A. Malavasi, A. Franco \& P. Franzoi. 2007. Comparative energy allocation in two sympatric, closely related gobies: the black goby Gobius niger and the grass goby Zosterisessor ophiocephalus. Journal of Fish Biology, 70: 483-496.

Garcia, D. A., E. Benedito \& A. M. Takeda 2010. Caloric density of Loricariichthys platymetopon in the Upper Paraná River floodplain. Brazilian Archives of Biology and Technology,
53: $1109-1118$

Glebe, B. D. \& W. C. Leggett. 1981. Latitudinal differences in energy allocation and use during the freshwater migrations of american shad (Alosa sapidissima) and their life history consequences. Canadian Journal of Fisheries and Aquatic Sciences, 38: 806-820.

Hendry, A. P., O. K. Berg \& T. P. Quinn. 2001. Breeding location choice in salmon: causes (habitat, competition, body size, energy stores) and consequences (life span, energy stores). Oikos, 93: 407-418.

Herbinger, C. M. \& G. W. Friars. 1991. Correlation between condition factor and total lipid content in Atlantic salmon, Salmo salar L., parr. Aquaculture and Fisheries Management, 22: 527-529.

Huntingford, F. A., S. Chellappa, A. C. Taylor \& R. H. Strang. 2001. Energy reserves and reproductive investment in male three-spined sticklebacks, Gasterosteus aculeatus. Ecology of Freshwater Fish, 10: 111-117.

Huss, M., P. Byström, A. Strand, L. O. Eriksson \& L. Persson. 2008. Influence of growth history on the accumulation of energy reserves and winter mortality in young fish. Canadian Journal of Fisheries and Aquatic Sciences, 65: 2149-2156.

Jonsson, B. \& N. Jonsson. 2005. Lipid energy reserves influence life history decision of Atlantic salmon (Salmo salar) and brown trout (S. trutta) in fresh water. Ecology of Freshwater Fish, 14: 296-301.

Jonsson, N. \& B. Jonsson. 1998. Body composition and energy allocation in life history stages of brown trout. Journal of Fish Biology, 53: 1306-1316.

Júlio Jr. H. F., S. M. Thomaz, A. A. Agostinho \& J. D Latini. 2005. Distribuição e caracterização dos reservatórios. Pp. 1-16. In: Rodrigues, L., S. M. Thomaz, A. A. Agostinho \& L. C. Gomes (Eds.). Biocenoses em reservatórios: Padrões espaciais e temporais. São Carlos: Rima, 2005.

Junk, W. J. 1985. Temporary fat storage an adaptation of some fish species to the river level fluctuations and related environmental changes of the Amazon river. Amazoniana, 9: 315-351.

Kaspari, M., L. Alonso \& S. O’Donnell. 2000. Three energy variables predict ant abundance at a geographical scale. Proceedings of the Royal Society, 267: 485-489.

Kitchell, J. F., J. J. Magnuson \& W. H. Neill. 1977. Estimation of caloric content for fish biomass. Environmental Biology of Fishes, 2: 185-188.

Le Cren, E. D. 1951. The length-weight relationship and seasonal cycle in gonad weight and condition in the perch (Perca fluviatis). Journal of Animal Ecology, 20: 201-219.

Luiz, E. A., A. C. Petry, C. S. Pavanelli, H. F. Júlio Jr., J. D Latini \& V. M. Domingues. 2005. As assembléias de peixes de reservatórios hidrelétricos do Estado do Paraná e bacias limítrofes. Pp. 169-184. In: Rodrigues, L., S. M. Thomaz, A. A. Agostinho \& L. C. Gomes (Eds.). Biocenoses em reservatórios: Padrões espaciais e temporais. São Carlos: Rima.

Nakatani, K., A. A. Agostinho, G. Baumgartner, A. Bialetzki, P. V. Sanches, M. C. Makrakis \& C. S. Pavanelli. 2001. Ovos e larvas de peixes de água doce: desenvolvimento e manual de identificação. EDUEM, Maringá.

Ngan, P. V., V. Gomes, D. M. de Morais \& M. J. Passos. 1993. Estudos bioenergéticos de animais marinhos costeiros. Boletino del instituto Oceanografico, 10: 199-215.

Nurnadia, A. A., A. Azrina \& I. Amin. 2011. Proximate 
composition and energetic value of selected marine fish and shellfish from the West coast of Peninsular Malaysia. International Food Research Journal, 18: 137-148.

Odum, E. P. 1988. Ecologia. Editora Guanabara, Rio de Janeiro.

Pandian, T. J. \& E. Vivekanandan, 1985. Energetics of feeding and digestion. Pp. 99-124. In: Tytler, P. \& P. Calow (Eds.). Fish Energetics: news perspectives. Croom Helm, Sydney.

Paul, A. J., J. M. Paul \& E. D. Brown. 1998. Fall and spring somatic energy content for Alaskan Pacific herring (Clupea pallasi Valenciennes, 1847) relative to age, size and sex. Journal of Experimental Marine Biology and Ecology, 223: 133-142.

Pedersen, J. \& J. R. G. Hislop. 2001. Seasonal variations in the energy density of fishes in the North Sea. Journal of Fish Biology, 59: 380-389.

Penczak, T., A. A. Agostinho, N. S. Hahn \& L. C. Gomes. 1999. Energy budgets of fish populations in two tributaries of the Paraná River, Paraná, Brazil. Journal of Tropical Ecology, 15: $159-177$.

Post, J. R. \& E. A. Parkinson 2001. Energy allocation strategy in young fish: allometry and survival. Ecology, 82: 1040-1051.

Prus, T. 1970. Calorific value of animals as an element of bioenergetical investigations. Polish Archives of Hydrobiology, 17: 183-199.

Querol, M. V. M., E. Querol, E. Pessano, C. L. O. Azevedo, D. Tomassoni, L. Brasil \& P. Lopes. 2003. Reprodução natural e induzida de Hoplias aff. malabaricus (Bloch, 1794), em tanques experimentais, na região de Uruguaiana, Pampa Brasileiro. Biodiversidade Pampeana, 1: 46-57.

Rezende, C. F., E. M. P. Caramaschi \& R. Mazzoni. 2008. Fluxo de energia em comunidades aquáticas, com ênfase em ecossistema lóticos. Oecologia Brasiliensis, 12: 629-639.

Saldaña, J. \& B. Venables. 1983. Energy compartmentalization in a migratory fish, Prochilodus mariae (Prochilodontidae), of the Orinoco River. Copeia, 1983: 617-623.
Soofiani, N. M. \& A. D. Hawkins, 1982. Energetics costs at different levels of feeding in juvenile cod, Gadus morhua L. Journal of Fish Biology, 21: 577-592.

Suzuki, H. I., A. A. Agostinho \& K. O. Winemiller. 2000. Relationship between oocyte morphology and reproductive strategy in loricariid catfishes of the Paraná River, Brazil. Journal of Fish Biology, 57: 791-807.

Suzuki, H. I. \& A. A. Agostinho, 1997. Reprodução de peixes do reservatório de Segredo. Pp. 167-182. In: Agostinho, A. A. \& L. C. Gomes (Eds.). Reservatório de Segredo: bases ecológicas para o manejo. EDUEM, Maringá.

Tirelli, V., D. Borme, F. Tulli, M. Cigar, S. Fonda Umani \& S. B. Brandt. 2006. Energy density of anchovy Engraulis encrasicolus L. in the Adriatic Sea. Journal of Fish Biology, 68: 982-989.

Tytler, P. \& P. Calow. 1985. Fish Energetics: news perspectives. Croom Helm, Sydney.

Vazzoler, A. E. A. M. 1981. Manual de métodos para estudos biológicos de populações de peixes: reprodução e crescimento. CNPq, Brasília.

Vazzoler, A. E. A. M. 1996. Biologia da reprodução de peixes teleósteos: teoria e prática. EDUEM, Maringá.

Vismara, M. R., E. Benedito-Cecilio \& A. C. A. Faria. 2004. Efeito da maturação gonadal sobre o conteúdo calórico e condição geral de peixes da planície de inundação do alto rio Paraná. Acta Scientiarum, 2: 189-199.

Watt, W. B. 1986. Power and the efficiency as index of fitness in metabolic organization. American Naturalist, 127: 629-653.

Zar, J. H. 1999. Biostatistical Analysis. Prentice Hall, New Jersey.
Submitted June 25, 2013

Accepted June 24, 2014 by Paulo Pompeu

Published December 27, 2014 